\title{
Investigations of Electric Power Quality in Autonomous Low Power Plant
}

\author{
Andrei Khitrov, Alexander Khitrov, Evgeny Veselkov, Vyacheslav Tikhonov \\ Pskov State University, Computer Science and Electric Power Engineering Faculty. Address: Russian \\ Federation, Pskov, Lenin square, 2.
}

\begin{abstract}
Autonomous low power electric power plants working with variable speed energy sources or electric subsystems of cogeneration plants of some type need to increase the low speed or the low voltage of the system. In this paper the investigations and the results of the experiments conducted using different structures are given.
\end{abstract}

Keywords: autonomous power supply system, permanent magnet synchronous machine, DC/DC converter, startergenerator set.

\section{INTRODUCTION}

The problem of increasing autonomous energy sector efficiency is settled in such legislative acts of the Russian Federation as Energy Strategy of Russia till both 2020 and 2030, government programs, etc. [1, 2, 3, 4]. Agency for Strategic Initiatives (Skolkovo) published a list of new professions in 2015. The following titles were introduced among them: «microgeneration systems developer», «recuperation systems projector», «local energy systems specialist», «energy storage developer».

Autonomous low power plants and generating sets will be high-demand in energy supply systems in remote areas, in emergency situations in case of power supply loss. It can be used as a system of backup for mobile power plants, for agriculture and housing and utilities infrastructure.

At the present time the most common and universal decentralized autonomous power supply systems (APSS) are diesel power stations (DPS) and gas-fired generation plants (GFGP). It usually has the power more than $50 \mathrm{~kW}$ and has a number of disadvantages which include the output power control problems. The promising alternative is APSS (cogeneration plants in particular) based on the external combustion engine (EC engine). The specific construction of the EC engine and the processes of thermal-to-mechanical energy conversion impose a number of issues for development of such power plant [5].

The aspects of structure designing the startergenerator set for autonomous cogeneration power plant based on the EC engine having rotary-vane construction (as well as the features and advantages of this type of engines) were considered in $[6,7]$.

Figure 1 shows the designed structure of the starter-generator set which has become the result of the first phase research. The simulation results using MATLAB program were considered in [6].

The second phase of research was devoted to the development of the experimental stand for live experiments. The issues of creating the experimental model as well as the investigations of staring mode of the rotary-vane EC engine (RVE) were considered in [8].

This article focuses on the continuation of the mentioned researches including the results of experiments conducted on the test stand.

\section{THE STRUCTURE}

Autonomous low power plant based on RVE requires increasing the output shaft speed (mechanical output of RVE) or increasing the output generator voltage. With fluctuations of speed it makes such system similar to so-called variable-speed systems.

The proposed structure, shown in fig. 1, is based on using the 3-phase permanent magnet synchronous motor (PMSM); this decision is a prospective for such systems [9].

Besides PMSM the diagram comprises three electric power converters: bidirectional active front end converter $1\left(\mathrm{AFE} / \mathrm{IN}_{1}\right), \mathrm{DC}$ link 2 including $\mathrm{DC} / \mathrm{DC}$ converter (power factor corrector) and inverter $3\left(\mathrm{IN}_{2}\right)$, and also corresponding control systems (CS AFE, CS DC/DC and CS IN) 4, 5, 6 for them.

DC link control is made in accordance with both fluctuations of the PMSM driving engine and fluctuations in the electric load by monitoring DC link voltage or current levels or the voltages or currents of the electric load at the output. 


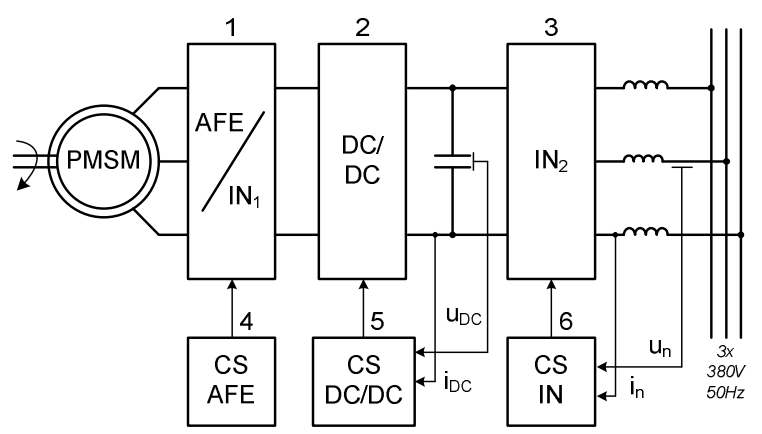

Fig. 1. The diagram of the autonomous generator plant with PMSM

To confirm the efficiency of the system proposed the experiments of monitoring the quality of autonomous plant generated power were conducted. The system had to meet (or partly meet) the quality indicators of current regulations. Monitoring the quality was conducted using power quality meter «Resource-UF2» and its proprietary software.

It is worth noting that there are no quality standards for the autonomous power plants in the Russian Federation. So monitoring the quality was performed with feeding the data standards from the general purpose power supply networks regulations of the Russian Federation (all-Union State Standard 32144-2013 [10]).

Fig. 2 shows the basic circuit diagrams of a series of experiments monitoring the quality of electric energy:

$a$ - preliminary experiment monitoring the quality of energy feeding the test stand, just the industrial network and the electric load;

$b$ - the industrial network works into the load via the rectifier and the inverter;

$c$ - the experiment with RVE work imitation and using PMSM and the transformer (T), the output generator voltage is boosted with the transformer;

$d$ - the experiment with RVE work imitation and using PMSM, the DC/DC converter and the structure proposed, the output generator voltage is boosted with the DC/DC.

Active and active-inductive load (including asynchronous motor) were connected and switched on and off during the experiment (load-on/load-off). The output inverter in circuit diagrams b, c, d (Fig. 2) was the same. a)

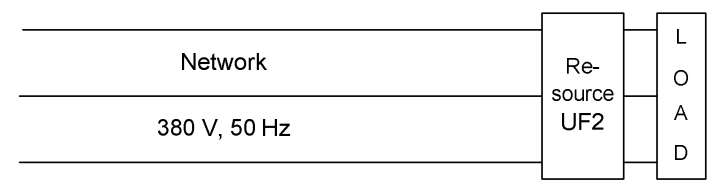

b)

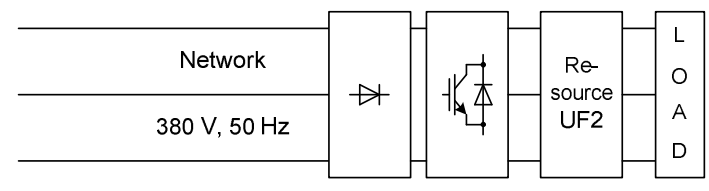

c)
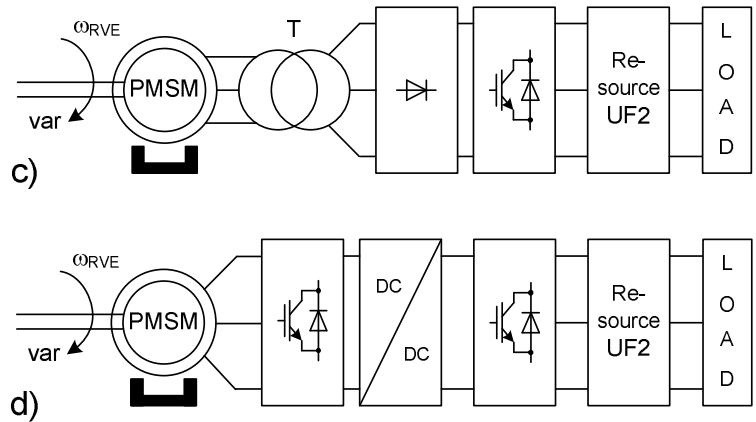

Fig. 2. Experiment circuit diagrams

\section{RESULTS AND DISCUSSION}

The measurements of power quality were produced for three-phase four-wire circuit. The following quality indicators were registered:

- Steady state voltage deviation.

- Voltage unbalance factor for negative phase sequence and zero phase sequence.

- Voltage nonsinusoidality ratio.

- Single harmonic distortion.

- Frequency deviation.

- Voltage dip duration.

- Voltage surge duration.

- Voltage dip depth.

- Temporary voltage surge ratio.

- Peak-to peak voltage fluctuations.

- Power-line flicker.

The usual parameters such as voltages, currents, phase angles, active and reactive power, active and reactive energy were also registered.

The frequency deviation from the rated value of $50 \mathrm{~Hz}$ for all of the above-mentioned circuits (Fig. 2) didn't exceed the value of $0.2 \mathrm{~Hz}$. Beyond that the frequency value can be adjusted accurately with inverter in case of parameter drift. Positive and negative rapid voltage changes didn't exceed the indicator of $5 \%$ from the rated value during the experiments (in the case of autonomous power plant the indicator values are values from the standard for low-voltage network). Fig. 3 shows the example of time diagrams of the output 3-phase voltage of the system for the structure Fig. 2, d. The y-axis is voltage value $(\mathrm{V})$, the $\mathrm{x}$-axis is current experiment time (hh:mm format, hereinafter the same designation for the X-axis). Voltage dip in Fig. 3 is caused by load 
switching on and is not above the voltage deviation limit.

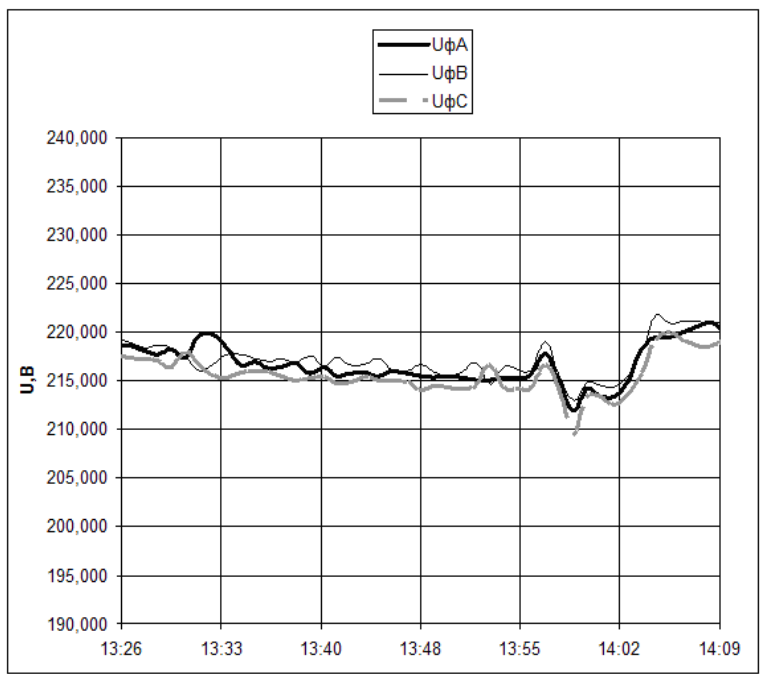

Fig. 3. Voltage time diagram

The values of voltage unbalance factor for negative phase sequence and zero phase sequence didn't exceed indicator value of $2 \%$ during the experiments.

Fig. 4 shows the time diagrams of the voltage nonsinusoidality ratio during the experiments conducted corresponding to different circuits (Fig. 2).
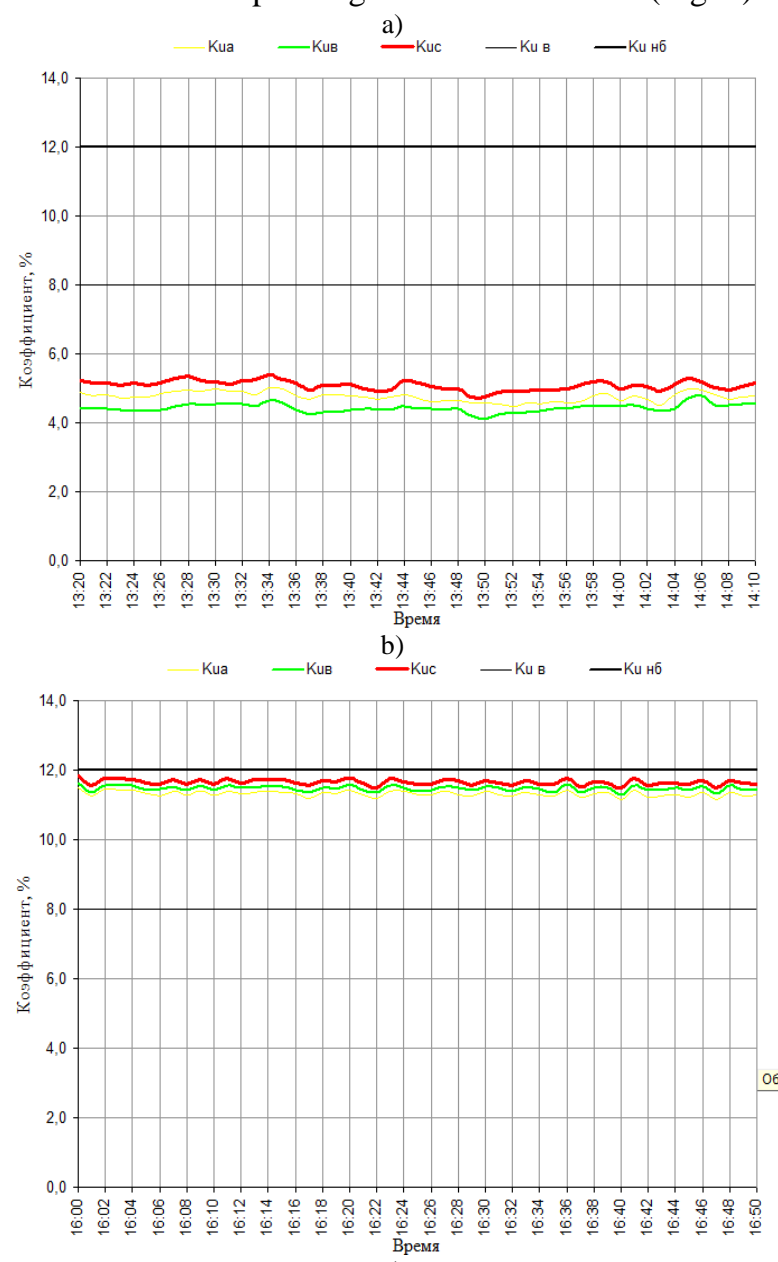

c)

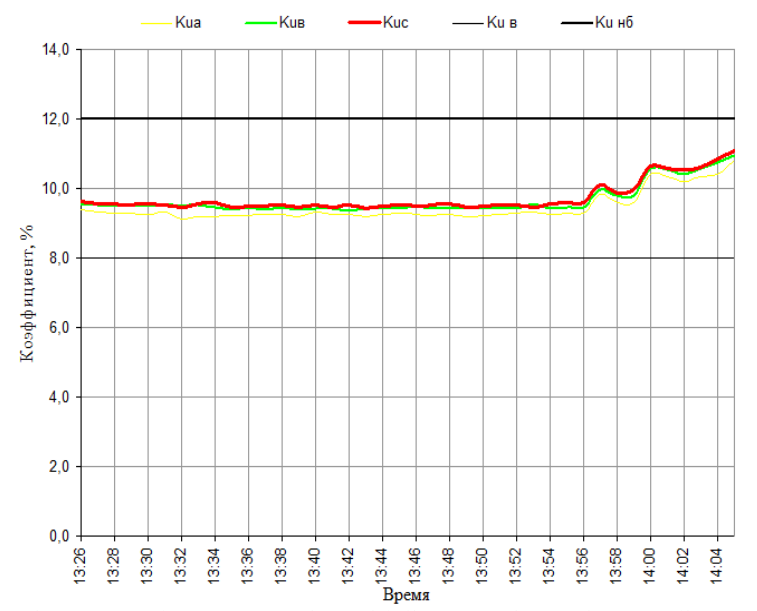

Fig. 4. Voltage nonsinusoidality ratio time diagrams corresponding to the experiments diagrams: a) Fig. 2. a, b) Fig. 2 , b, c) Fig.2, d

The value of voltage nonsinusoidality ratio has exceeded the permissible by the standard indicator value during the experiments corresponding to the structures containing the inverter at the output: the structures b, c, d in Fig. 2. The permissible indicator value for this ratio is $8 \%$ during $95 \%$ of time. At the same time the second indicator value $(12 \%$ during $100 \%$ of time) wasn't exceeded.

The value of voltage nonsinusoidality ratio during the experiment corresponding to the diagram Fig. 2, d (DC/DC + inverter) was lower (Fig. 4, c) than during the experiment corresponding to the diagram Fig. 2, b (network + inverter, Fig. 4, b corresponds to the circuit Fig. 2, b). In this two experiments the work of low-speed motor with variable speed was simulated. Fig. 4, a shows the value of voltage nonsinusoidality ratio of the industrial network (4-6\%) and corresponds to the diagram Fig. 2, a.

Hence, it can be concluded that the use of DC/DC converter in autonomous power supply system in order increase the voltage doesn't increase such quality indicator as voltage nonsinusoidality ratio (moreover, some decrease was registered).

Notations for the Fig.4: $\mathrm{K}_{\mathrm{UA}}, \mathrm{K}_{\mathrm{UB}}, \mathrm{K}_{\mathrm{UC}}$ - voltage nonsinusoidality ratio values in phases $\mathrm{A}, \mathrm{B}, \mathrm{C}$, respectively, $\mathrm{K}_{\mathrm{UB}}$ - upper limit, the value should not be exceeded during $95 \%$ of time, $\mathrm{K}_{\mathrm{UнБ}}-$ maximum limit, the value should not be exceeded during $100 \%$ of time.

When powered from the industrial network (Fig. 2 , a) the value of any single harmonic component didn't exceed the permissible indicator values. The value of the 3-rd harmonic component was about $4 \%$, 5-th $-3.5 \%$, 7-th and 9-th - about $1 \%$, and the rest components were less than $0.5 \%$.

When powered from the structure containing inverter (Fig. 2, b) the values of any even harmonic component, except 2-nd and 4-th, exceeded the permissible single harmonic values. Also the appearance of higher harmonics should be stated: 1$2 \%$ from the 8 -th and up to 40 -th. 
When powered from the structure containing DC/DC converter (Fig. 2, d) the output voltage has the same distortions as that in experiment corresponding to the diagram Fig. 2, b. Also all the even harmonic components appeared (at the same time the appearance of even harmonics doesn't cause a general increase in the voltage nonsinusoidality ratio). Even harmonic components also appear during the experiment corresponding to the structure Fig. 2, c (containing transformer). The appearance of even harmonics during the experiment corresponding to the structures containing PMSM can be explained by the peculiarities of DVU2M series synchronous motor application as a generator.

Voltage surges and voltage dips caused by switching various loads on and off didn't exceed the permissible indicator value of 1 minute.

\section{CONCLUSION}

Output voltage distortions observed when the load is powered from the structure containing DC/DC and inverter are similar to the distortions observed when there is no intermediate multiplier DC-link. It allows to conclude about the necessity of completing such autonomous low-power plant with the inverter having high quality output voltage and the capability to be connected to DC-link (the output of the DC/DC converter).

The experiments conducted on the test stand have confirmed the efficiency of the low-power plant (electric part of cogeneration plant) based on RVE. The quality of electric power generated by the electric part of the plant meets all the indicator parameters of all-Union State Standard 32144-2013 except the voltage nonsinusoidality ratio.

\section{V.ACKNOWLEDGMENTS}

This study is supported by Foundation for Assistance to Small Businesses in Science and Technology (the program «UMNIK» in Pskov Region in particular) [11]. The contract number is $11003 G U 2 / 2016$.

\section{REFERENCES}

[1] Об энергосбережении и о повышении энергетической эффективности и о внесении изменений в отдельные законодательные акты Российской Федерации / Федеральный закон № 261 от 23.11.2009.

[2] Энергетическая стратегия России до 2030 г. / утверждена Распоряжением Правительства России от 13 ноября 2009 года № 1715-p.

[3] Об Энергетической стратегии России на период до 2020 года / Распоряжение Правительства РФ от 28.08.2003 N 1234-p (ред. от 15.06.2009).

[4] Энергоэффективность и развитие энергетики / Государственная программа РФ, утверждена постановлением правительства РФ от 15 апреля 2014 г. № 321.

[5] Плохов И.В., Донченко М.А., Лукьянов Ю.Н. Энергоэффективная автономная энергоустановка нового поколения. Доклад на международной конференции «Инновационные технологии 2009». М.:Иннотехэкспо, 2009.

[6] Khitrov A.I., Khitrov A.A. Electrical subsystem of the low power cogeneration plant with low-speed vehicle. Environment. Technology. Resourses. Proceeding of the 9th International Scientific and Practical Conference, 2013. Volume II. Rezekne. pp.119-123.

[7] Перминов А. Л., Хитров А. А., Хитров А. И. Мехатронная система «магнитоэлектрический синхронный двигатель - активный выпрямитель» для автономной системы электроснабжения на базе роторнолопастной машины с внешним подводом тепла. Труды VII Международной (VIII Всероссийской) конференции по автоматизированному электроприводу АЭП-2012: ФГБОУВПО "Ивановский государственный энергетический университет им. Ленина". - Иваново, 2012. c. $330-335$

[8] Khitrov A.A. Khitrov A.I. Investigation of permanent magnet synchronous machine with recuperation block». Proceedings of the 10-th International Scientific and Practical Conference «Environment. Technology. Resources. Volume I. Rezekne, Latvia, 2015. pp. 53-56.

[9] Харитонов С. А. Электромагнитные процессы в системах генерирования электрической энергии для автономных объектов. - Новосибирск: Изд-во НГТУ, 2011. - 536 р.

[10] ГОСТ 32144-2013. Нормы качества электрической энергии в системах электроснабжения общего назначения. - Москва, Стандартфинорм, 2014. - 16 р.

[11] Foundation for Assistance to Small Businesses in Science and Technology: http://umnik.fasie.ru/o-fonde/ 